\title{
Is the Global Competitiveness Report the right measure of macroeconomic competitiveness ${ }^{*}$
}

\author{
Marko Djogo ${ }^{1}$, Nenad Stanisic ${ }^{2}$
}

\begin{abstract}
The purpose of this paper is to research the effect of abandoning the assumption of long-term time horizon in terms of reliability of the Global Competitiveness Report (GCR) findings. In order to achieve this goal we will compare the GCR findings with the findings of a composite index of competitiveness, named 6 BIC (Basic Indicators of Competitiveness). We have developed this index on the theoretical basis provided by Krugman, Fagerbergs, Scott, Lodge, Aiginger and others. Economists are aware that any theoretical conception, including the GCR, relies on a number of assumptions and postulations. If some of those have been under scrutiny, then the whole construction and its findings would lose their credibility. One of the most significant assumptions rooted in the Global Competitiveness Report is its longevity. In the long-term, the change in productivity level through price competitiveness certainly brings out a change in outcome competitiveness level. However, the effects in short-to-middle term are not certain. Our findings show that there is a whole range of countries whose national competitiveness is either under-estimated by the GCR (for example Russia, Turkey, Estonia, Moldova) or overvalued (Finland, Ireland, Iceland, Portugal, Spain) in short-to-middle term. The basic conclusion from the obtained results of the research is that the GCR does not provide sufficiently good view of the current competitiveness of the countries, and that this indicator needs to be extended also with other competitiveness indicators, such as those selected in our paper.
\end{abstract}

Key words: macro-competitiveness, productivity level, basic indicators of competitiveness

JEL classification: E20, F40

\footnotetext{
Received: 16-01-2016; accepted: 17-06-2016

1 Assistant Professor, Faculty of Economics, University of East Sarajevo, Alekse Šantića 3, 71420 East Sarajevo, Bosnia and Herzegovina. Scientific affiliation: international economy. Phone: +38766903411.E-mail:markodjogo@yahoo.com,marko.djogo@ekofis.org.

2 Associate Professor, Faculty of Economics, University of Kragujevac, Đure Pucara Starog 3, 34000 Kragujevac, Serbia. Scientific affiliation: international economy. Phone: +38164662 6676.E-mail:nstanisic@open.telekom.rs,nstanisic@kg.ac.rs.
} 


\section{Introduction}

Every year the World Economic Forum (WEF) publishes the Global Competitiveness Report (GCR) which draws a lot of attention of academic and general public, especially in countries ranked low at this list. However, historical fact is that just few decades ago, more precisely, as recently as until the second half of the $20^{\text {th }}$ century, macro-competitiveness was unheeded issue even in academic community. Actually, competitiveness used to be understood as an issue suitable for measurement only at some lower levels, usually at level of enterprises where it represents their capability to create, produce, sale and service its product or its commercial services (Kovačević, 2010:3). Since then, the situation dramatically changed. Macroeconomic competitiveness became important issue. But even today there is some antagonism toward this concept and wide spread use of it. In the community of the so-called development economists (Chang, 2007: 5), there is a well known attitude of Paul Krugman, the Nobel prize laureate for economics in 2008 who had described macrocompetitiveness as "dangerous obsession" (Krugman, 1994), and that "a matter of time honored fallacies about international trade being dressed up in a new and pretentious rhetoric" (Krugman, 1996: 18). This attitude still has a lot of supporters among economists and others who believe in the importance of government interventionism ${ }^{3}$. Although, this attitude is based on some deeper economic issues, it could be explained very simply. One of the basic presumptions for defining macrocompetitiveness is related to the existence of free and fair trade. That means that companies from different countries should compete on the imagined world market under fair conditions, and that their success or failure is what makes every country competitive/uncompetitive (Neslihan and Hüseyin, 2012). But, beside the long term efforts of the World Trade Organization (WTO) and others, the presumption about free and fair trade is highly unrealistic (Salvatore, 2009: 36) just like the presumption about the existing of a perfect free market within national borders. On the top of it, many Keynesian economists argue that even if it is possible to achieve perfect free and fair trade it is not always the best thing to do. They think that if development of less developed countries (LDC) has to be promoted then it is necessary to "tilte the playing field" (Chang, 2007: 217-220) in favor of LDCs. But even Krugman admitted the importance of this dangerous obsession by defining it in this way: "Competitiveness is capability of country to keep its current account in balance along with improving standards of living" (Kovačević, 2010: 5). In this Krugman's definition, major elements can be found which are recognized by majority of traditional researchers of this issue (Aiginger et al., 2013: 1). On the contrary to Krugman's opinion WEF's Report is "coloured" by Michael Porter's understanding of competitiveness as a measure of productivity: "the only meaningful concept of competitiveness at national level is national productivity" (Porter, 1998: 6). Of course,

3 For example: Clinton, B. (2012). The subtitle of this book is: Why We Need Smart Government for a Strong Economy. 
we are not questioning the long-term relation between the country's productivity level and its macro-competitiveness. However, we believe that when you use such a wide spectrum of indicators based on the current productivity level, there has to exist a time gap between changes in some of those indicators and considerable change of the macro-economic position of the country in the world. Moreover, macroeconomic position could be changed in short time without any level of change in productivity, for example, through currency devaluation (Tomaš, 2011). Thus, relying on the definitions of macro-competitiveness made by a few well known authors in this field, we have designed a composite index of macro-competitiveness and have named it 6BIC (6 Basic Indicators of Competitiveness). These were made in an attempt to research the current competitiveness position of countries and to compare it with the findings made in the Global Competitiveness Report.

The hypothesis we want to test is that WEF's definition of macroeconomic competitiveness and the following methods used for the measurement of competitiveness, although useful in long term, are not the best solution for the measurement of current macroeconomic competitiveness, what users of that Report should have in mind. Reason for this should be questioned in time gap between a change in the level of productivity of the country and the macroeconomic performance of that country in a short time period. Alternative point of view is why we need the outcome-based competitiveness index provided by Ulengin (2002) who noticed that GCR depends on a number of qualitative factors, which, in turn depends on the perception of executives. In addition, "outcome" competitiveness is under influence of many non-economic factors which are not part of WEF's eleven pillars of competitiveness. Good examples for those are political integration and politically motivated foreign investment in some countries without any change in economic environment. On the other hand, fast and furious reforms of economic environment bring about the fast climbing at WEF's Report rank-list without noticeable impact on export performance, economic growth, employment, income etc., in short time period.

The paper is organized in the following manner: Section 2 provides readers with the current knowledge connected with the problem of defining the macroeconomic competitiveness in a unique way. Section 3 describes the methodology and conception used for analysis. Section 4 contains data and empirical results of the analysis. Section 5 provides the interpretation of results with explanations. Some conclusions and directions for future research and public are provided in Section 6.

\section{Literature review}

Literature about macroeconomic competitiveness is today so rich that it is not possible to provide unique list of all important works in this economic field. 
Therefore, we believe that the best and maybe the only possible way to do so is to refer to the most frequently used definitions of macroeconomic competitiveness.

OECD definition of macro-competitiveness is quite similar to Krugman's one. That definition goes like this: "Macro-competitiveness is capability of country to, in fair market conditions, produce goods and services which could pass test of international market, along with long term holding or increasing of real income of citizens" (Šajatović, 2015) Similar definition is offered by European Commission: "The ability of an economy to provide its population with high and rising standards of living and high rates of employment on a sustainable basis" (European Commission, 2001). We do not need to go any further to recognize huge differences in conceptualizing the meaning of macroeconomic competitiveness between the OECD, EC and Krugman on one hand, and WEF and Porter on the other hand, about. WEF accepted the view of Michael Porter, the author of the world famous book Competitive Advantage of Nation that competitiveness should be measured "in root" meaning by the cause and not by results. Thus Porter stresses that the capabilities of a country to achieve long term economic growth and to increase the standards of living of its citizens primarily depends on the level of productivity in using the resources of the country (Porter, 1998). Similar definition was accepted by WEF. WEF definition is based on eleven factors (pillars) of productivities. Although this is unquestionably a useful approach, we daresay its domination in the modern economy is unjustified. We believe that competitiveness, except through analysing the factors of productivity, should be measured and directly - by outcomes. In order to support this attitude we will present a few more definitions given by well-known authors and institutions.

Jan Fagerberg, one of the leading authorities in the field of competitiveness during the second part of the $20^{\text {th }}$ century defined competitiveness as: "Capability to achieve main economic goals, including growth of income and employment, without emerging of balance of payment deficit". (Fagerberg, 1988: 355). As it could be seen, Fagerberg argued that in competitive countries, the increase of living standards should come not only by the increasing of real income, but also by creating new jobs.

Similar definition, was given recently by Karl Aiginger, Susanne Barenthaler-Sieber and Johanna Vogel in this way: "competitiveness became associated with the ability of a region or country to create value added and employment or to improve living standards" and upgraded in: "ability of a country (region, location) to deliver the beyond-GDP goals for its citizens" (Aiginger et al., 2013: 1).

B. Scott and G. Lodge defined competitiveness as: "capability of a country to use its resources with high efficiency according to international specialization and trade, so that in the end, it brings to rise of real income and to improvement of the standard of living, all of that based on real categories, not on borrowing abroad" (Scott and 
Klodge, 1985: 15). In this definition it is important to note that Scott and Lodge emphasize the importance of not borrowing abroad, what was the conventional way of thinking until the end of the 1980s. But in the world of disappearing borders this condition had been wasted with more or less good explanation. As far as until the beginning of 1980s, when globalization started, majority of countries in East Europe, Asia and Africa had been running in some kind of closed, self-protected economy. In that circumstance, the increase of export could be achieved along with a sharp increase of external public debt, because governments were capable to channel public debt in investments. Today, this is not possible, because in circumstances of open economy, almost every rise of public expenditure brings about the increase of imports and thus the declining of competitive position of the country if we use the export performance as the basic indicator of competitiveness. In that way, the rise of public external debt is just another side of the country's un-competitiveness. But, experience in the last couple of years, especially in the countries of South-East Europe (irresponsible governments) made us believe that this condition (of not borrowing abroad, or at least, of not increasing external public debt) should be returned in the definitions of macroeconomic competitiveness.

So, the elements which we believe are not enough emphasized in WEF's definition of competitiveness are: a dynamic economic growth with creation of enough new jobs, balanced current account, investments, absence of increasing external public debts and ecological sustainable development. From all those elements, Professor Mlađen Kovačević (2010: 9-11), directly made objection to the absence of investment rate, trade deficit and country's external debt in WEF's Report.

That is what made us brave enough to offer our own definition of macroeconomic competitiveness based on "the shoulders of splendors", i.e. derivative from previously given definitions that were given by respectable people in this field. Out definition of the so-called outcome competitiveness is the following: "Macroeconomic competitiveness is the capability of a country, in free and fair market conditions, to keep its trade account balanced, with dynamic economic growth which through creating new jobs and increasing real earnings brings about the improvement of standard of living, all of that achieved along with satisfactory investment rate, without increasing external public debt and without breaching environment."

\section{Methodology and method of analysis}

To test the hypothesis in which we have defined the composite index of competitiveness $-6 \mathrm{BIC}$ - contains the following six indicators of competitiveness of a nation: balance of current account, unemployment rate, annual cost of salary per worker, external debt, economic growth rate and investment rate. As data source 
for previous indexes we have used secondary source, mostly WBG databases and databases of national central banks and statistical institutes.

Because those six indicators are expressed in different measuring systems, practically it is impossible to compare the values of entities in different variables (indicators), which makes the forming of the composite index very hard. To solve this problem we used the method of transformation of the original value of variables to standardized or z-values.

Process of standardization has been done through next equation:

$$
z_{i j}=\frac{x_{i j}-\dot{x}_{j}}{s_{j}}
$$

where symbols represent: $z_{i j}$-standardized result of entity $i$ to variable $j ; x_{i j}$ - original value of entity $i$ to variable $j$; $\dot{\mathrm{x}}_{j}-$ arithmetic mean of variable $j ; s_{j}$ - standard deviation of variable $j$.

From the previous equation it is easy to comprehend that after being derived from the valuation of entity deviation from arithmetic mean (centering the result) the standardized value, has been divided by standard deviation. So, the standardized value is a relative measure of the standard variance expressed as a part of the standard deviation.

Composite index $6 \mathrm{BIC}$ has been calculated as the non-weighted average of the standardized value of the six variables (at unemployment rate and external debt with negative value).

The result of the calculated 6 BIC index for about forty countries was used for ranking them according to the level of their competitiveness. The ranking achieved in this way was compared with their rank according to every of six indicators respectively, and with their rank of competitiveness from the Global Competitiveness Report.

If there is a high level of correlation between the rank of competitiveness according to the Global Competitiveness Report and the rank of competitiveness according to 6BIC index then we have to reject our hypothesis that the GCR very well represents the level of current competitiveness. In the other case we will take our hypothesis as proved.

Before we present our final results we will look back on the interpretation of each of our six basic indicators of competitiveness. 


\section{Empirical data and analysis}

We used eleven different data sources, most frequently from WBG Official website, OECD official website and the Europe's central banks sites, what could be seen from the text below.

Balance of Trade Account and Competitiveness. Before we construct our full index of competitiveness according to method $6 \mathrm{BIC}$, we wanted to determine where European countries are according to the criteria of trade surplus/deficit and by another basic criterion which we included in our definition of macroeconomic competitiveness. As we previously mentioned, trade surplus/deficit were not used in Global Competitiveness Report as one of the indicators. But we believe that trade surplus or, at least, balanced trade volume with the rest of the word is a condition sine qua non to the macroeconomic competitiveness ${ }^{4}$. All other criteria have only corrective meaning in the way that term competitiveness improve in term sustainable and/or social acceptable competitiveness. To express this in another way - even if the country meets all the other criteria of competitiveness from our definition, but records a substantial trade deficit, the country should be considered as low-competitive. Data about trade surplus/deficit of European countries are presented in table 1 .

Table 1: Competitiveness of European countries by criterion trade surplus/deficit in 2014

\begin{tabular}{|l|c|c|c|}
\hline \multicolumn{1}{|c|}{ Country } & $\begin{array}{c}\text { Trade surplus/deficit } \\
\text { (\% of GDP) }\end{array}$ & $\begin{array}{c}\text { Rank by criterion trade } \\
\text { surplus/deficit } \\
\text { (amid 39 countries) }\end{array}$ & GCR ranks \\
\hline Luxembourg & 35.2 & 1 & 10 \\
\hline Ireland & 20.8 & 2 & 13 \\
\hline Switzerland & 12.1 & 3 & 1 \\
\hline Norway & 10.7 & 4 & 7 \\
\hline Netherland & 10.3 & 5 & 15 \\
\hline Iceland & 8.3 & 6 & 29 \\
\hline Hungary & 7.6 & 7 & 32 \\
\hline Slovenia & 6.0 & 8 & 25 \\
\hline Russia & 5.9 & 10 & 18 \\
\hline Czech Republic & 5.8 & & \\
\hline
\end{tabular}

\footnotetext{
$\overline{4}$ We know for some historical examples of countries that became relatively rich by selling natural resources (Guatemala, Argentina etc.), and then again relatively poor when circumstances changed. Similar current examples are Russia and Norway in Europe. But we disagree that this means that trade surplus/deficit is irrelevant when we talk about macroeconomic competitiveness.
} 
Table 1 (continuation)

\begin{tabular}{|l|c|c|c|}
\hline Denmark & 5.8 & 11 & 8 \\
\hline Germany & 5.8 & 12 & 3 \\
\hline Sweden & 4.9 & 13 & 6 \\
\hline Malta & $4.7(2011)$ & 14 & 23 \\
\hline Slovakia & 4.6 & 15 & 33 \\
\hline Austria & 3.6 & 16 & 11 \\
\hline Spain & 3.5 & 17 & 16 \\
\hline Italia & 2.3 & 18 & 24 \\
\hline Poland & 1.9 & 19 & 21 \\
\hline Portugal & 1.0 & 20 & 17 \\
\hline Estonia & 0.9 & 21 & 14 \\
\hline Croatia & 0.4 & 22 & 35 \\
\hline Romania & -0.5 & 23 & 28 \\
\hline Bulgaria & -0.6 & 24 & 26 \\
\hline Finland & -0.9 & 25 & 2 \\
\hline France & -1.5 & 26 & 12 \\
\hline Lithuania & $-1.5(2011)$ & 27 & 19 \\
\hline UK & -1.9 & 28 & 5 \\
\hline Belarus & -2.8 & 29 & n.a. \\
\hline Greece & -3.0 & 30 & 36 \\
\hline Latvia & $-3.9(2011)$ & 31 & 20 \\
\hline Turkey & -6.6 & 32 & 22 \\
\hline Ukraine & -8.5 & 33 & 34 \\
\hline Serbia & -11.1 & 34 & 38 \\
\hline Albania & -17.8 & 35 & 39 \\
\hline FJR Macedonia & -18.9 & 36 & 37 \\
\hline Montenegro & -20.3 & 39 & 37 \\
\hline B\&H & -21.1 & & \\
\hline Moldavia & -37.7 & 37 & \\
\hline & & 29 & \\
\hline
\end{tabular}

Source: World Bank data site, http://data.worldbank.org/indicator/NE.EXP.GNFS.ZS and http:// data.worldbank.org/indicator/NE.IMP.GNF S.ZS, date of access: April 15, 2015

As it could be seen, from 39 European countries, 21 had a trade surplus, while 18 had a trade deficit. It is interesting to note that at the very top of the list based on the criterion trade surplus/deficit, there are the same countries ranked very high at the Global Competitiveness Report list (Switzerland, Norway, Netherland etc.). But, 
the whole group of countries ranked very low in the Global Competitiveness Report are ranked relatively high by criterion trade surplus/deficit (for example Hungary, Slovenia, Russia) which questions Porter's and WEF's view of them as (currently) uncompetitive countries. Also, UK and Finland are in top 15 at the Global Competitiveness Report list although those are the countries with a trade deficit. It is also interesting to notice that the Balkans countries (B\&H, Serbia, Montenegro, FJR Macedonia, Albania), hold quite strongly the last positions on this rank-list of competitiveness among European countries.

Unemployment rate and competitiveness. Macroeconomic balance based on a low level of the life standard is not unknown, but it does not fit to our understanding of macro-competitiveness. That is why we used the unemployment rate as an additional criterion. Although high unemployment rate naturally leads to a low absorption level, meaning at the same time a low level of imports, keeping trade in balance in this way is socially unacceptable. European countries competitiveness by criterion of the level of unemployment is given in table 2 .

Table 2: Rank-list of European Countries by criteria of level of unemployment in 2014

\begin{tabular}{|l|c|c|c|}
\hline Country & $\begin{array}{c}\text { Unemployment rate } \\
(\%)\end{array}$ & $\begin{array}{c}\text { Rank by criteria of } \\
\text { unemployment rate } \\
\text { (among 41 countries) }\end{array}$ & GCR ranks \\
\hline Norway & 3.5 & 1 & 7 \\
\hline Switzerland & 4.4 & 2 & 1 \\
\hline Austria & 4.9 & 3 & 37 \\
\hline Moldavia & 5.1 & 4 & 3 \\
\hline Germany & 5.3 & 5 & 25 \\
\hline Russia & 5.6 & 6 & 15 \\
\hline Iceland & 5.6 & 7 & n.a. \\
\hline Belarus & 5.8 & 8 & 10 \\
\hline Luxembourg & 5.9 & 9 & 23 \\
\hline Malta & 6.5 & 10 & 4 \\
\hline Netherland & 6.7 & 11 & 8 \\
\hline Czech Republic & 6.9 & 12 & 28 \\
\hline Denmark & 7 & 13 & 34 \\
\hline Romania & 7.3 & 14 & 6 \\
\hline UK & 7.5 & 15 & 2 \\
\hline Ukraine & 7.9 & 16 & \\
\hline Sweden & 8.1 & 17 & 18 \\
\hline Finland & 8.2 & & \\
\hline & & & \\
\hline
\end{tabular}


Table 2 (continuation)

\begin{tabular}{|c|c|c|c|}
\hline Belgium & 8.4 & 19 & 9 \\
\hline Estonia & 8.8 & 20 & 14 \\
\hline Turkey & 10 & 21 & 22 \\
\hline Hungary & 10.2 & 22 & 29 \\
\hline Slovenia & 10.2 & 23 & 32 \\
\hline Poland & 10.4 & 24 & 21 \\
\hline France & 10.4 & 25 & 12 \\
\hline Latvia & 11.1 & 26 & 20 \\
\hline Lithuania & 11.8 & 27 & 19 \\
\hline Italia & 12.2 & 28 & 24 \\
\hline Bulgaria & 12.9 & 29 & 26 \\
\hline Ireland & 13.1 & 30 & 13 \\
\hline Slovakia & 14.2 & 31 & 33 \\
\hline Cyprus & 15.8 & 32 & 27 \\
\hline Albania & 16 & 33 & 39 \\
\hline Portugal & 16.5 & 34 & 17 \\
\hline Croatia & 17.7 & 35 & 35 \\
\hline Montenegro & 19.8 & 36 & 31 \\
\hline Serbia & 22.2 & 37 & 38 \\
\hline Spain & 26.6 & 38 & 16 \\
\hline Greece & 27.3 & 39 & 36 \\
\hline $\mathrm{B} \& \mathrm{H}$ & 28.4 & 40 & n.a. \\
\hline FJR Macedonia & 29 & 41 & 30 \\
\hline
\end{tabular}

Source: World Bank data site: http://data.worldbank.org/indicator/SL.UEM.TOTL.ZS, date of access: April 19, 2015

There is almost entirely the same situation as with the previous criterion. A few countries highly ranked at the Global Competitiveness Report list are at the same time in the top of our list of countries with the lowest unemployment rate (for example Norway, Switzerland, Germany and Luxembourg), while at the same time there are the same countries such as Russia, Belarus and Moldova that are low ranked at the Global Competitiveness Report list but highly ranked at our list. There is even the third group - countries highly ranked at the Global Competitiveness Report list which record unemployment rate over $10 \%$ (France, Ireland, Spain, Portugal), the levels usually considered as really high.

Annual cost of salary per worker and competitiveness. Annual cost of salary per worker should be considered as an additional criterion to the previous one (to 
unemployment rate). Our understanding of macroeconomic competitiveness suggests that it is not enough if the country has a balanced trade exchange with the rest of the world and low unemployment rate. Salary in suc a country should also be high enough to enable decent life standard. It is certainly possible for a country to achieve both a balanced trade exchange and a high employment rate through cutting salaries at life-existence minimum level but in our opinion that is still not real competitiveness. For example, beside other measures, many communist countries in East Europe for decades used low real salaries to maintain what they proclaimed to be macroeconomic sustainability, but no one seriously consider them as really competitive countries.

Why this criterion should be changed or abandoned with the transition of these countries into some kind of free trade and free market economies? That is not what was promised to citizens of those countries at the beginning of the transition process.

In the previous text we did not explain why we did not use the so-called cost per output indicator when even Eurostat publishes it for a majority of European countries on annual basis. Simply, it was not our intention to measure the level of labour efficiency which is exactly what this indicator (cost per output) could show us. Our intention was to find out what workers get for their efforts. We are also aware that a better solution would be to use annual cost of salaries modified by the purchasing power parity (PPP), but unfortunately we could not find the source that would contain data for more than 25 to 30 European countries. We found that calculation of salaries per worker with PPP for the rest of European countries was too complicated for us to deal with, while the elimination of something like ten European countries from our list was not an option, so, at the end, we decided to use the simpler but wider available indicator - annual salaries per worker. However, we believe that, in the relatively limited area, as Europe is, with liberal trade exchange and relatively stable exchange rates, this indicator is good enough for our purposes.

Table 3: Ranking of European countries by criterion of annual cost of salaries per worker in 2014

\begin{tabular}{|l|c|c|c|}
\hline Country & $\begin{array}{c}\text { Annual cost of salary } \\
\text { per worker }(€)\end{array}$ & $\begin{array}{c}\text { Rank by criteria } \\
\text { annual cost of salary } \\
\text { per worker (amid 41 } \\
\text { European countries) }\end{array}$ & GCR ranks \\
\hline Switzerland & 69,910 & 1 & 1 \\
\hline Norway & 59,980 & 2 & 7 \\
\hline Luxembourg & 58,570 & 3 & 10 \\
\hline Denmark & 54,425 & 4 & 13 \\
\hline Ireland & 49,983 & 5 & 4 \\
\hline Netherland & 44,610 & 6 & \\
\hline
\end{tabular}


Marko Djogo, Nenad Stanisic • Is the Global Competitiveness Report the right measure...

Table 3 (continuation)

\begin{tabular}{|c|c|c|c|}
\hline Belgium & 41,746 & 7 & 9 \\
\hline Sweden & 40,654 & 8 & 6 \\
\hline UK & 39,995 & 9 & 5 \\
\hline Iceland & 39,858 & 10 & 15 \\
\hline Finland & 39,628 & 11 & 2 \\
\hline Austria & 39,069 & 12 & 11 \\
\hline Germany & 35,675 & 13 & 3 \\
\hline France & 35,238 & 14 & 12 \\
\hline Italia & 28,070 & 15 & 24 \\
\hline Cyprus & 27,504 & 16 & 27 \\
\hline Spain & 21,470 & 17 & 16 \\
\hline Slovenia & 21,470 & 18 & 32 \\
\hline Greece & 17,988 & 20 & 36 \\
\hline Malta & 16,267 & 19 & 23 \\
\hline Portugal & 15,325 & 21 & 17 \\
\hline Estonia & 13,025 & 22 & 14 \\
\hline Croatia & $12,642^{5}$ & 23 & 35 \\
\hline Slovakia & 11,939 & 24 & 33 \\
\hline Turkey & 11,583 & 25 & 22 \\
\hline Czech Republic & 10,990 & 26 & 18 \\
\hline Poland & 10,421 & 27 & 21 \\
\hline Hungary & 9,791 & 28 & 29 \\
\hline Montenegro & 8,676 & 29 & 31 \\
\hline Russia & 8,406 & 30 & 25 \\
\hline $\mathrm{B} \& \mathrm{H}$ & 7,938 & 31 & n.a. \\
\hline Lithuania & 8,574 & 32 & 19 \\
\hline Serbia & 7,102 & 33 & 38 \\
\hline Latvia & 6,888 & 34 & 20 \\
\hline Romania & 6,776 & 35 & 28 \\
\hline FJR Macedonia & 6,292 & 36 & 30 \\
\hline Bulgaria & 5,734 & 37 & 26 \\
\hline Belarus & 4,750 & 38 & n.a. \\
\hline
\end{tabular}

5 Authors' calculation based on data from Croatian Bureau of Statistics (2015), Average monthly gross earning of persons in paid employment for December 2014, Zagreb. Available at: http://www.dzs.hr/ [Accessed: April 20, 2015] and The Croatian National Bank, Exchange rate list. Available at: https:// www.hnb.hr/temeljne-funkcije/monetarna-politika/tecajna-lista/tecajna-lista [Accessed: April 20, 2015]. 
Marko Djogo, Nenad Stanisic • Is the Global Competitiveness Report the right measure...

Table 3 (continuation)

\begin{tabular}{|l|l|l|l|}
\hline Ukraine & 3,696 & 39 & 34 \\
\hline Albania & 3,207 & 40 & 39 \\
\hline Moldavia & $2,453^{6}$ & 41 & 37 \\
\hline
\end{tabular}

Source: Authors' calculation based on data from OECD data site, https://stats.oecd.org/Index. aspx?DataSetCode=AV_AN_WAGE, date of access: April 21, 2015. and Bloomberg data site: http://www.bloomberg.com/quote/EURUSD:CUR, date of access: April 21, 2015

It is interesting to note that out of all the indicators we used, the highest degree of matching is between the ranks of the countries by this indicator (annual cost of salary per worker) and ranks by the Global Competitiveness Report. This relation demonstrates that, opposite to the conventional opinion how the easiest way to become a competitive economy is through reducing the general level of wages, actually the most competitive economies are those with the highest salary per worker. So, nine from ten European countries with the highest salary per worker

${ }^{6}$ Data for Montenegro is for 2014 year. Authors' calculation based on data from: http://www. tradingeconomics.com/montenegro/wages [Accessed: April 20, 2015], Data for Russia is for 2013 year. Authors' calculation based on data from report: Labor cost in Central and Easter Europe, edition 2014, CE Research, Warszawa, Available at: http://www.databasece.com/en/average-salary, [Accessed: April 20, 2015], Data for Bosnia is for 2013 year. Authors' calculation based on Central Bank of Bosnia and Herzegovina Data from Bulletin No. 3, 2014. Available at: http://www.cbbh. ba/files/bilteni/2014/Bilten_3_2014.pdf [Accessed: April 22, 2015], Data for Lithuania is for 2014 year Authors' calculation based on data from Trading Economics data site. Available at: http://www. tradingeconomics.com/lithuania/wages [Accessed: April 22, 2015], Data for Latvia is for 2014 year. Authors' calculation based on data from Trading Economics data site. Available at: http://www. tradingeconomics.com/latvia/wages [Accessed: April 22, 2015], Data for Romania is for 2014 year. Authors' calculation based on data from Trading Economics data site. Available at: http://www. tradingeconomics.com/romania/wages [Accessed: April 22, 2015], Data for Macedonia is for 2014 year. Authors' calculation based on data from Trading Economics data site. Available at: http://www. tradingeconomics.com/macedonia/wages [Accessed: April 22, 2015], Data for Bulgaria is for 2014 year Authors' calculation based on data from Trading Economics data site. Available at: http://www. tradingeconomics.com/bulgaria/wages [Accessed: April 22, 2015], Data for Belarus is for 2012 year. Authors' calculation based on National Statistical Committee Data from Bulletin, Statistical Review of Belarus January-March 2013. Available at: http://belstat.gov.by/en/bgd/katalog-publikatsii/ public bulletin/ [Accessed: April 23, 2015], Data for Ukraine is for 2013 year. Authors' calculation based on data from report: Labor cost in Central and Easter Europe, edition 2014. CE Research, Warszawa. Available at: http://www.databasece.com/en/average-salary [Accessed: April 23, 2015], Data for Albania is for 2014 year. Authors' calculation based on The Institute of Statistics, Statistical databases, wages and labor costs. Available at: http://www.instat.gov.al/en/figures/statisticaldatabases.aspx [Accessed: April 18, 2015], and Bank of Albania, Exchange rates Archive, arhttp:// www.bankofalbania.org/web/exchange_rates_archive_2372_2.php [Accessed: April 23, 2015], Data for Moldova is for 2013 year. Authors' calculation based on: National Bureau of Statistics of the Republic of Moldova, Earnings statistics, Wage Statistics, AVERAGE MONTHLY NOMINAL EARNING PER EMPLOYEE IN ECONOMY, BY ECONOMIC ACTIVITIES, in 2013, and National bank of Moldova, Exchange rate. Available at: http://www.bnm.md/en/official_exchange rates [Accessed: April 24, 2015]. 
are at the same time also the most competitive European countries according to the Global Competitiveness Report. The most distinguished example is Switzerland, the country where the average employee receives almost 70,000 € per year (the country with the highest average wage in Europe) and at the same time country no. 1 at WEF's Global Competitiveness Report for 2014/15. But, this result is actually expected because we are talking about ex-post analysis. More precisely, if a country is to keep the level of salaries above the average for a long period in conditions of free trade, that country has to ensure the level of productivity above the average. That is an explanation for this connection.

External debt and competitiveness. As already emphasized, the definitions of macro-competitiveness until the end of the 1980s often referred to external debt (its absence) and, with an increasing borrowing by the residents of developed countries, most authors began to omit this criterion, considering that external debt is not a problem as long as it is sustainable and that it would be wrong not to take into account the reasons for its emergence (often used is the example of the USA as a country whose external debt, especially public debt, rapidly grows and whose economy is considered to be highly competitive). However, after the occurrences in Greece, we believe that it is time to revert the external debt to the definitions of macro-competitiveness, thus it is clear that accumulation of external debt, especially external public debt, is potentially detrimental for one country's economy. It is interesting to note from table A1 (Appendices) that the countries of Eastern Europe and the Balkans are among the least indebted in Europe (Estonia, Russia, Moldova, Bulgaria, Belarus) while some of the most indebted countries are those with a capitalist tradition (Greece, Italy, Iceland, Portugal, Ireland, Cyprus, Belgium). Although this can partly be explained with the impossibility of borrowing for the communist countries' residents until two or three decades ago (which is not the case when it comes to external public debt since most of these countries were IMF members or members of the World Bank), we still believe that these data show an underestimated competitiveness of the Eastern European countries and an overestimated competiveness of the Western European countries.

The economic growth rate and competitiveness. Economy which is not providing dynamic and stabile rates of economic growth is certainly not to be considered competitive. Thereby, it is logical to expect the real economic growth rates to be lower in developed countries than in those which are still in the lower stages of development. However, taking into account a turbulent global environment in the last seven-eight years, which should by definition be more harmful to undeveloped countries than to the developed ones, we argue that the real economic growth rate is a very relevant indicator of countries' competitiveness.

In turn, it is interesting to note from table A2 (Appendices) that at the peak of competitiveness, regarding the rate of economic growth in the last five years, there are some countries of Eastern and South-Eastern Europe. In fact, the top five 
positions are occupied by Turkey, Belarus, Moldova, Poland and Albania, while solidly placed are also Russia, Macedonia and Slovakia. In front rows, along with newer EU member states, are all the countries of Southern Europe, longstanding EU and EMU member states (Greece, Italy, Portugal, Spain). It is interesting to notice that some of them, despite many years of recession and an obvious overindebtedness, are still among better placed European countries in the WEF's competitiveness report (Spain, Portugal).

Investment rate and competitiveness. This is one of the criteria of competitiveness, on which professor Kovacevic (2010: 10) particularly insisted in the above mentioned paper. Despite the fact that it can be objected that the investment rate itself does not indicate their quality (structure) and that it is a question of the indicator that will affect competitiveness in the future directly through productivity on which Global Competitiveness Index insists, we believe there is also room for it to be in 6BIC.

The competitiveness of European countries regarding the investment rate is given in the table A3 in Appendices. It is once again interesting to notice that the highest investment rates are in Eastern European countries (seven out of ten countries with the highest investment rates are from this group) while the smallest investments are in the war-affected Ukraine, recession-affected Greece, and on two islands that were recently affected by financial (banking) crisis (Cyprus and Iceland). Also surprising is a relatively low investment rate in the UK since it is a country highly ranked on the WEF's Global Competitiveness Report.

\section{Results and discussion}

After bringing out the details on competitiveness of European countries on six criteria that have found their place in our definition of macro-competitiveness derived on the basis of observations of recognized authors in this field, it is time to access the summarization of all these indicators into one index and to draw a comparison of obtained results (ranking) with the findings of the WEF. Table 4 shows ranking of the countries according to the composite 6BIC index of competitiveness which we have constructed as described above.

It is interesting to notice that, according to our 6BIC index, the leading country in terms of competitiveness is Norway (which is according to GCR ranked seventh). It is followed by Switzerland, which is in GCR ranked first, after it Luxembourg (ranked tenth according to GCR). The worst-ranked in our table are the countries of the region (Bosnia and Herzegovina and Macedonia) and countries of Southern Europe, members of the Eurozone which have been in serious economic and financial crisis in the last years (Greece and Portugal), whereby these countries are worst-ranked according to GCR as well. 
Marko Djogo, Nenad Stanisic $\bullet$ Is the Global Competitiveness Report the right measure...

Table 4: Ranking of European countries by criterion of 6BIC in 2014

\begin{tabular}{|c|c|c|}
\hline Country & GCR ranks & 6BIC ranks \\
\hline Albania & - & 26 \\
\hline Austria & 11 & 10 \\
\hline Belgium & - & 18 \\
\hline $\mathrm{B} \& \mathrm{H}$ & - & 39 \\
\hline Great Britain & 5 & 23 \\
\hline Bulgaria & 26 & 21 \\
\hline Greece & 36 & 41 \\
\hline Denmark & 8 & 8 \\
\hline Estonia & 14 & 5 \\
\hline Ireland & 13 & 24 \\
\hline Iceland & 15 & 29 \\
\hline Italy & 24 & 30 \\
\hline Latvia & 20 & 33 \\
\hline Lithuania & 19 & 25 \\
\hline Luxemburg & 10 & 4 \\
\hline Hungary & 29 & 28 \\
\hline Macedonia & 30 & 37 \\
\hline Malta & 23 & 17 \\
\hline Moldavia & 37 & 19 \\
\hline Norway & 7 & 1 \\
\hline Germany & 3 & 12 \\
\hline Poland & 21 & 11 \\
\hline Portugal & 17 & 38 \\
\hline Romania & 28 & 20 \\
\hline Russia & 25 & 7 \\
\hline Slovakia & 33 & 22 \\
\hline Slovenia & 32 & 27 \\
\hline Serbia & 38 & 31 \\
\hline Turkey & 22 & 9 \\
\hline Ukraine & 34 & 35 \\
\hline Finland & 2 & 16 \\
\hline France & 12 & 14 \\
\hline Netherlands & 4 & 13 \\
\hline Croatia & 35 & 32 \\
\hline Montenegro & 31 & 34 \\
\hline Czech Republic & 18 & 15 \\
\hline Switzerland & 1 & 2 \\
\hline Sweden & 6 & 6 \\
\hline Spain & 16 & 36 \\
\hline
\end{tabular}

Note: GCR - global competitiveness report index; 6BIC - six basic indicators of competitiveness (composite index).

Source: Authors' calculation 
The greatest discrepancy between the rankings in our composite 6BIC index and in GCR is in the case of:

- Russia, Turkey, Estonia, Luxembourg and Moldova, which are much better ranked in the 6BIC index than in the GCR, as well as in the case of:

- Finland, Ireland, Iceland, Portugal and Spain, which have lower ranking in the $6 \mathrm{BIC}$ index than in the GCR.

From the above mentioned, it can be concluded that our indicator is more sensitive to the current economic situation in the countries than GCR, owing to the fact that it pays more regard to the reality arising from recent economic and financial crises. We believe that precisely this sensitivity to the current economic situation promotes the use of 6BIC as an indicator of current competitiveness, meaning that its usage is not in conflict with the usage of GCR's findings that keeps its role of the main indicator of long-term competitiveness. It might be said that this is an indicator which can be used parallel to the GCR, without bringing in question the GCR's findings which represent a strong indication of the direction in which the competing position of the countries is going to move in the long term.

Using the software tools IBM SPSS 21 we have correlated the ranks of the countries regarding their competitiveness based on 6 basic indicators individually, based on GCR and composite 6BIC index. Table 5 shows the results of rank correlation, along with the corresponding estimations of statistical significance of correlation.

The greatest statistically significant rank correlation is between the GCR and labour costs per employee (0.782) and composite 6BIC index and unemployment rate $(0.766)^{7}$. Correlation between GCR and labour costs is, as already presented, expected to be significant since it is an ex-post connection. Namely, in order to be possible to pay high wages to employees over a longer period of time and under the circumstances of an open market, it is necessary for labour productivity to be high.

Since GCR is based precisely on productivity, the connection is obvious. On the other hand, very high and significant rank correlation between our composite 6BIC index and unemployment rate is in favour of our intention that competitiveness has to greatly respect one of the most basic indicators of every economy - (un)employment rate. Since economics is neither technical nor natural, but social science, and since employees are not just one of the factors of production, we believe that especially the findings strongly connecting our composite $6 \mathrm{BIC}$ index to the unemployment rate promote its wider usage among professional and general public.

\footnotetext{
Positive value of correlation reflects the fact that the countries are ranked regarding unemployment from the one with the lowest unemployment rate (assigned rank 1) to the one with the highest unemployment rate. On that note, positive correlation between composite $6 \mathrm{BIC}$ index and the rank regarding unemployment rate indicates the fact that highly-ranked countries according to 6BIC index are at the same time those with the lowest unemployment rates.
} 
Marko Djogo, Nenad Stanisic $\bullet$ Is the Global Competitiveness Report the right measure...

Table 5: Rank correlations

\begin{tabular}{|c|c|c|c|c|c|c|c|c|c|}
\hline \multicolumn{10}{|c|}{ Correlations } \\
\hline \multicolumn{2}{|c|}{ Indicators } & Trade & Unempl. & Labor_cost & Debt & Growth & $\begin{array}{l}\text { Invest- } \\
\text { ments }\end{array}$ & GCI & Composite \\
\hline \multirow{3}{*}{ Trade } & $\begin{array}{l}\text { Pearson } \\
\text { Correlation }\end{array}$ & 1 & $.478^{* *}$ & $.673^{* *}$ & -.147 & -.087 & -.171 & $.516^{* *}$ & $.470^{* *}$ \\
\hline & Sig. (2-tailed) & & .002 & .000 & .386 & .602 & .311 & .001 & .003 \\
\hline & $\mathrm{N}$ & 38 & 38 & 38 & 37 & 38 & 37 & 36 & 38 \\
\hline \multirow{3}{*}{$\begin{array}{l}\text { Unemploy- } \\
\text { ment }\end{array}$} & $\begin{array}{l}\text { Pearson } \\
\text { Correlation }\end{array}$ & $.478^{* *}$ & 1 & $.319^{*}$ & .310 & $.383^{*}$ & .267 & $.510^{* *}$ & $.766^{* *}$ \\
\hline & Sig. (2-tailed) & .002 & & .042 & .051 & .013 & .101 & .001 & .000 \\
\hline & $\mathrm{N}$ & 38 & 41 & 41 & 40 & 41 & 39 & 36 & 41 \\
\hline \multirow{3}{*}{ Labor_cost } & $\begin{array}{l}\text { Pearson } \\
\text { Correlation }\end{array}$ & $.673^{* *}$ & $.319^{*}$ & 1 & $-.368^{*}$ & -.147 & -.276 & $.782^{* *}$ & $.372^{*}$ \\
\hline & Sig. (2-tailed) & .000 & .042 & & .019 & .360 & .089 & .000 & .016 \\
\hline & $\mathrm{N}$ & 38 & 41 & 41 & 40 & 41 & 39 & 36 & 41 \\
\hline \multirow{3}{*}{ Debt } & $\begin{array}{l}\text { Pearson } \\
\text { Correlation }\end{array}$ & -.147 & .310 & $-.368^{*}$ & 1 & $.467^{* *}$ & $.660^{* *}$ & -.071 & $.487^{* *}$ \\
\hline & Sig. (2-tailed) & .386 & .051 & .019 & & .002 & .000 & .687 & .001 \\
\hline & $\mathrm{N}$ & 37 & 40 & 40 & 40 & 40 & 38 & 35 & 40 \\
\hline \multirow{3}{*}{ Growth } & $\begin{array}{l}\text { Pearson } \\
\text { Correlation }\end{array}$ & -.087 & $.383^{*}$ & -.147 & $.467^{* *}$ & 1 & $.433^{* *}$ & .142 & $.597^{* *}$ \\
\hline & Sig. (2-tailed) & .602 & .013 & .360 & .002 & & .006 & .410 & .000 \\
\hline & $\mathrm{N}$ & 38 & 41 & 41 & 40 & 41 & 39 & 36 & 41 \\
\hline \multirow{3}{*}{ Investments } & $\begin{array}{l}\text { Pearson } \\
\text { Correlation }\end{array}$ & -.171 & .267 & -.276 & $.660^{* *}$ & $.433^{* *}$ & 1 & .012 & $.506^{* *}$ \\
\hline & Sig. (2-tailed) & .311 & .101 & .089 & .000 & .006 & & .944 & .001 \\
\hline & $\mathrm{N}$ & 37 & 39 & 39 & 38 & 39 & 39 & 35 & 39 \\
\hline \multirow{3}{*}{ GCI } & $\begin{array}{l}\text { Pearson } \\
\text { Correlation }\end{array}$ & $.516^{* *}$ & $.510^{* *}$ & $.782^{* *}$ & -.071 & .142 & .012 & 1 & $.609^{* *}$ \\
\hline & Sig. (2-tailed) & .001 & .001 & .000 & .687 & .410 & .944 & & .000 \\
\hline & $\mathrm{N}$ & 36 & 36 & 36 & 35 & 36 & 35 & 36 & 36 \\
\hline \multirow{3}{*}{ Composite } & $\begin{array}{l}\text { Pearson } \\
\text { Correlation }\end{array}$ & $.470^{* *}$ & $.766^{* *}$ & $.372^{*}$ & $.487^{* *}$ & $.597^{* *}$ & $.506^{* *}$ & $.609^{* *}$ & 1 \\
\hline & Sig. (2-tailed) & .003 & .000 & .016 & .001 & .000 & .001 & .000 & \\
\hline & $\mathrm{N}$ & 38 & 41 & 41 & 40 & 41 & 39 & 36 & 41 \\
\hline
\end{tabular}

Note: * Correlation is significant at the 0.05 level (2-tailed)

${ }^{* *}$ Correlation is significant at the 0.01 level (2-tailed).

Source: Authors' calculation (in IBM SPSS 21)

Rank correlation, according to our composite 6BIC index and GCR, is 0.609 and thus statistically significant. Although high, this correlation is not among the top 5 , so it is to conclude that this confirms our initial hypothesis that GCR does not provide sufficiently good view of the current competitiveness of the countries, and that this indicator should additionally be extended with other competitiveness indicators, such as those selected in our paper. 


\section{Conclusion}

The hypothesis tested has confirmed the initial aim to demonstrate that WEF's definition of macroeconomic competitiveness and the following methods used for the measurement of competitiveness, although useful in long term, are not the best solution for the measurement of current macroeconomic competitiveness. The obtained results of the research confirm that the 6BIC indicator is more sensitive to the current economic situation in the countries than the GCR. Thus, to a greater extent, it takes into account the reality arising from recent economic and financial crises. Therefore 6BIC indicator is a small contribution to economic theory because although there are plenty of definitions of macro-competitiveness in economic theory, representing the attitudes of respectable economists on the nature of competitiveness, there are only few competitiveness indices. Actually, the indices of competitiveness are created mainly by institutions and seldom by individuals. Among these indices, the most dominating and the most used one is the Global Competitiveness Index of WEF, which is, however, based on the understanding of competitiveness as productivity which is not the attitude of many well-known economists. Therefore, the creation of 6BIC index is an attempt of reaffirmation of one way of thinking which understands competitiveness primarily through the output results. This paper is also an attempt to provide scientific contribution to the reconciliation of the understanding of competitiveness as productivity with the understanding of competitiveness through the results by including the issue of time period in consideration. The 6BIC indicator also contains a lot of imperfections. The 6BIC is actually too simple. The peril of the authorities in countries with decreasing productivity abusing the index as an excuse for their irresponsibility and passive behaviour is also recognized. There is a wide space for the improvement of the 6BIC through increasing the number of indicators included in observation and through including weights of indicators. It is the weight of indicators and connections between them that should be investigated in future papers, which would provide additional importance to this paper. In order to explain how the 6BIC can be used by the authorities to design an economic policy, the GCI and 6BIC would be described as indicators of trends and indicators of stock. In principle, for the entire observation of economic issues, it is preferable to have both kinds of indicators (trend and stocks) because it provides a more complete picture.

\section{References}

Aiginger, K., Barenthaler-Sieber, S. Vogel, J. (2013) Competitiveness under New Perspectives, Brussels: European Commission - Welfare-Wealth-Work.

Bank of Albania site: Exchange rates Archive. Available at: http://www.bankofalbania. org/web/exchange_rates_archive_2372_2.php [Accessed: April 18, 2015]. 
Bloomberg data site: Exchange rates Archive. Available at: http://www.bloomberg. com/quote/EURUSD:CUR [Accessed: April 19, 2015].

CE Research (2014) Labor Costs in Central and Eastern Europe, edition 2014, Warszawa: CE Research Press.

Central Bank of Bosnia and Herzegovina (2014) Buliten, Vol. 3-2014, Sarajevo, Central Bank of Bosnia and Herzegovina Press. Available at: http://www.cbbh. ba/files/bilteni/2014/Bilten_3_2014.pdf [Accessed: April 22, 2015].

Chang, H-J. (2007) Bad Samaritans: Rich Nations, Poor Policies and the Threat to the Developing World, London: Random House Business Books.

Clinton, B. (2012) Back to Work: Why We Need Smart Government for a Strong Economy, Zagreb: MATE Zagreb Ltd.

Croatian Bureau of Statistics (2015) Average monthly gross earning of persons in paid employment for December 2014, Zagreb: Croatian Bureau of Statistics Press.

Croatian National Bank, Exchange rate list. Available at: https://www.hnb.hr/ temeljne-funkcije/monetarna-politika/tecajna-lista/tecajna-lista [Accessed: April 20, 2015].

Economics Help data site. Available at: http://www.economicshelp.org/blog/774/ economics/list-of-national-debt-by-country/ [Accessed: April 25, 2015].

Economy Watch data site. Available at: http://www.economywatch.com/economicstatistics/economic-indicators/Investment_Percentage_of_GDP/2014/ [Accessed: April 26, 2015].

European Commission (2001) Competitiveness of European Manufacturing, Brussels, DG Enterprise.

Fagerberg, J. (1988) "Industrial Competitiveness", The Economic Journal, Vol. 98, No. 391, pp. 355-374, doi: 10.2307/2233372.

Institute of Statistics of Albania, Statistical databases, wages and labour costs. Available at: http://www.instat.gov.al/en/figures/statistical-databases.aspx [Accessed: April 18, 2015].

Kovacevic, M. (2010) "Cause of decline and low level of Serbia economy competitiveness". In Proceeding of the symposia: How to increase level of competitiveness and export of Serbia, September 29-30, Kragujevac: Economic Faculty in Belgrade, pp. 3-40.

Krugman, P. (1994) "Competitiveness a dangerous obsession", Foreign Affairs, Vol. 73, No. 2, pp. 28-44, doi: 10.2307/20045917.

Krugman, P. (1996) "Making sense of the competitiveness debate", Oxford Review of Economic Policy, Vol. 12, No. 3, pp. 17-25, doi: 10.1093/oxrep/12.3.17.

National Bank of Moldova data site, Exchange rate. Available at: http://www.bnm. md/en/official_exchange_rates [Accessed: April 24, 2015]. 
National Bureau of Statistics of the Republic of Moldova (2014) Earnings statistics, Wage Statistics, Average Monthly Nominal Earning per Employee in Economy, by Economic Activities in 2013, Kishinev.

National Statistical Committee of Belarus (2013) Statistical Review of Belarus January-March 2013, Minsk. Available at: http://belstat.gov.by/en/bgd/katalogpublikatsii/public bulletin/ [Accessed: April 18, 2015].

Neslihan, A. and Hüseyin, T. (2012) "Defining and Measuring Competitiveness: A Comparative Analysis of Turkey with 11 Potential Rivals", International Journal of Basic and Applied Sciences IJBAS-IJENS, Vol. 12, No. 2, pp. 31-43.

OECD data site, Average Annual Wages. Available at: https://stats.oecd.org/Index. aspx?DataSetCode=AV_AN_WAGE [Accessed: April 21, 2015].

Porter, M. (1998) The Competitive Advantage of Nations: With a new introduction, (Rev. ed.) New York: Free Press.

Salvatore, D. (2009) International Economics (Ninth Edition), Belgrade: Economic Faculty in Belgrade.

Scott, B., Klodge, G. (1985) US Competitiveness in the World Economy, Boston: Harvard Business School Press.

Šajatović, M. (2015) “O konkurentnosti”, National Competitiveness Council of Croatia [Internet]. Available at: http://www.konkurentnost.hr/Default. aspx?sec=77 [Accessed: April 15, 2015].

Tomaš, V. (2011) "National Competitiveness and Expenditure on Education, Research and Development", Journal of Competitiveness, Vol. 2, Tomas Bata Universitu in Zlin, Faculty of Management and Economics, pp. 3-10.

Trading Economics data site. Available at: http://www.tradingeconomics.com/ lithuania/wages [Accessed: April 22, 2015], http://www.tradingeconomics.com/ latvia/wages [Accessed: April 22, 2015], http://www.tradingeconomics.com/ romania/wages [Accessed: April 22, 2015], http://www.tradingeconomics.com/ macedonia/wages, [Accessed: April 23, 2015], http://www.tradingeconomics. com/bulgaria/wages [Accessed: April 22, 2015].

Ulengin, F. et al. (2002) "A power-based measurement approach to specify macroeconomic competitiveness of countries", Socio-Economic Planning Sciences, Vol. 36, No. 3, pp. 203-226, doi: 10.1016/s0038-0121(01)00021-0.

World Bank data site. Available at: http://data.worldbank.org/indicator/NE.EXP. GNFS.ZS [Accessed: April 15, 2015], http://data.worldbank.org/indicator/ NE.IMP.GNF S.ZS [Accessed: April 15, 2015], http://data.worldbank.org/ indicator/SL.UEM.TOTL.ZS [Accessed: April 19, 2015], http://data.worldbank. org/indicator/NY.GDP.MKTP.KD.ZG [Accessed: April 22, 2015].

World Economic Forum (2014) Global Competitiveness Report 2014-15, New York: Oxford University Press. 


\title{
Je li Globalno izvješće o konkurentnosti prava mjera makro-konkurentnosti
}

\author{
Marko Djogo ${ }^{1}$, Nenad Stanisic ${ }^{2}$
}

\begin{abstract}
Sažetak
Cilj ovoga rada je istražiti može li se značajnije utjecati na pouzdanost nalaza Globalnog izvješća konkurentnosti (GCR) napuštanjem pretpostavke o dugoročnom vremenskom horizontu. Da bi se postigao ovaj cilj uspoređuju se nalazi GCR-a s nalazima koje smo dobili korištenjem kompozitnog indeksa konkurentnosti, nazvanog 6 BIC (Bazičnih indikatora konkurentnosti). Ovaj pokazatelj razvijen je oslanjajući se na teoretske osnove koje su utemeljili Krugman, Fagerberg, Scott, Lodge, Aiginger $i$ drugi. Ekonomisti su svjesni da je svaka ekonomska konstrukcija, uključujući $i$ Globalni indeks konkurentnosti temeljena na nizu pretpostavki $i$ postulata. Ako se neka od tih pretpostavki relativizira tada i rezultati do kojih se dolazi korištenjem ove teoretske konstrukcije gube na snazi. Jedna od važnijih pretpostavki koja se nalazi u osnovi Globalnog izvješća o konkurentnosti je dugi rok. U dugom roku, rast produktivnosti svakako vodi prema poboljšanju konkurentnosti. Međutim u kratkom i srednjem roku taj utjecaj nije tako izvjestan. Rezultati do kojih se došlo pokazuju da postoji čitav niz zemalja čiji položaj ili je podcijenjen (Rusija, Turska, Estonija, Moldavija i druge) ili precijenjen (Finska, Irska, Island, Portugal, Španjolska i druge) po GCR-u u kratkom do srednjeg roka. Temeljni zaključak dobivenih rezultata istraživanja je da GIK ne pruža dovoljno dobru sliku tekuće konkurentnosti te da ovaj pokazatelj treba biti dopunjen drugim pokazateljima konkurentnosti, kao što su ovi korišteni u radu.
\end{abstract}

Ključne riječi: makro-konkurentnost, produktivnost, temeljni indikatori konkurentnosti

JEL klasifikacija: E20, F40

${ }^{1}$ Docent, Ekonomski fakultet, Univerzitet u Istočnom Sarajevu, Alekse Šantića 3, 71420 Istočno Sarajevo, Bosna i Hercegovina. Znanstveni interes: međunarodna ekonomija. Tel.: +387 66903 411.E-mail:markodjogo@yahoo.com,marko.djogo@ekofis.org.

2 Izvanredni profesor, Ekonomski fakultet, Univerzitet u Kragujevcu, Đure Pucara Starog 3, 34000 Kragujevac, Srbija. Znanstveni interes: međunarodna ekonomija. Tel.: +381 64662 6676.E-mail:nstanisic@open.telekom.rs,nstanisic@kg.ac.rs. 


\section{Appendices}



Marko Djogo, Nenad Stanisic •Is the Global Competitiveness Report the right measure...

Table A1: Ranking of European countries by criterion of external public debt

\begin{tabular}{|c|c|c|c|}
\hline Country & $\begin{array}{l}\text { External public debt } \\
\text { (as \% of GDP) }\end{array}$ & $\begin{array}{l}\text { Rank by criteria } \\
\text { external public debt } \\
\text { (amid } 41 \text { countries) }\end{array}$ & GCR ranks \\
\hline Estonia & 6.0 & 1 & 14 \\
\hline Russia & 7.9 & 2 & 25 \\
\hline Moldavia & 16.6 & 3 & 37 \\
\hline Bulgaria & 18.4 & 4 & 26 \\
\hline Luxemburg & 22.9 & 5 & 10 \\
\hline Norway & 30.1 & 6 & 7 \\
\hline Belarus & 31.5 & 7 & n.a. \\
\hline Switzerland & 33.8 & 8 & 1 \\
\hline Macedonia & 34.3 & 9 & 30 \\
\hline Turkey & 36.6 & 10 & 22 \\
\hline Romania & 38.6 & 11 & 28 \\
\hline Latvia & 39.2 & 12 & 20 \\
\hline Lithuania & 40.2 & 13 & 19 \\
\hline Ukraine & 40.6 & 14 & 34 \\
\hline Sweden & 41.5 & 15 & 6 \\
\hline $\mathrm{B} \& \mathrm{H}$ & 45.9 & 16 & n.a. \\
\hline Denmark & 47.0 & 17 & 8 \\
\hline Poland & 48.2 & 18 & 21 \\
\hline Czech Republic & 48.8 & 19 & 18 \\
\hline Montenegro & 52.1 & 20 & 31 \\
\hline Slovakia & 55.5 & 21 & 33 \\
\hline Finland & 56.5 & 22 & 2 \\
\hline Serbia & 61.2 & 23 & 38 \\
\hline Croatia & 66.2 & 24 & 35 \\
\hline Albania & 70.5 & 25 & 39 \\
\hline Slovenia & 71.1 & 26 & 32 \\
\hline Netherlands & 74.3 & 27 & 4 \\
\hline Malta & 75.0 & 28 & 23 \\
\hline Austria & 75.7 & 29 & 11 \\
\hline Germany & 79.9 & 30 & 3 \\
\hline Great Britain & 91.1 & 31 & 5 \\
\hline France & 93.4 & 32 & 12 \\
\hline Spain & 93.7 & 33 & 16 \\
\hline Belgium & 102.4 & 34 & 9 \\
\hline Cyprus & 113.0 & 35 & 27 \\
\hline Ireland & 124.2 & 36 & 13 \\
\hline Portugal & 127.8 & 37 & 17 \\
\hline Iceland & 130.1 & 38 & 15 \\
\hline Italy & 133.0 & 39 & 24 \\
\hline Greece & 175.0 & 40 & 36 \\
\hline
\end{tabular}

Source: Economics.help data site: http://www.economicshelp.org/blog/774/economics/list-ofnational-debt-by-country/, date of access: April 25, 2015 
Marko Djogo, Nenad Stanisic $\bullet$ Is the Global Competitiveness Report the right measure...

Table A2: Ranking of European countries by criterion of GDP growth in last 5 years

\begin{tabular}{|c|c|c|c|}
\hline Country & $\begin{array}{l}\text { GDP growth in last } 5 \\
\text { years }(2008=100 .)\end{array}$ & $\begin{array}{l}\text { Ranks by GDP growth } \\
\text { (amid } 41 \text { countries) }\end{array}$ & GCR ranks \\
\hline Turkey & 120.21 & 1 & 22 \\
\hline Belarus & 116.83 & 2 & n.a. \\
\hline Moldavia & 116.27 & 3 & 37 \\
\hline Poland & 115.44 & 4 & 21 \\
\hline Albania & 113.20 & 5 & 39 \\
\hline France & 107.28 & 6 & 12 \\
\hline Malta & 106.94 & 7 & 23 \\
\hline Macedonia & 106.80 & 8 & 30 \\
\hline Switzerland & 105.75 & 9 & 1 \\
\hline Russia & 105.26 & 10 & 25 \\
\hline Slovakia & 105.01 & 11 & 33 \\
\hline Sweden & 104.43 & 12 & 6 \\
\hline Norway & 103.70 & 13 & 7 \\
\hline Luxemburg & 103.34 & 14 & 10 \\
\hline Germany & 102.31 & 15 & 3 \\
\hline Austria & 102.18 & 16 & 11 \\
\hline Belgium & 101.84 & 17 & 9 \\
\hline Great Britain & 101.47 & 18 & 5 \\
\hline Estonia & 100.72 & 19 & 14 \\
\hline Montenegro & 100.47 & 20 & 31 \\
\hline Serbia & 100.40 & 21 & 38 \\
\hline $\mathrm{B} \& \mathrm{H}$ & 100.01 & 22 & n.a. \\
\hline Bulgaria & 99.14 & 23 & 26 \\
\hline Iceland & 98.45 & 24 & 15 \\
\hline Romania & 98.18 & 25 & 28 \\
\hline Lithuania & 98.12 & 26 & 19 \\
\hline Czech Republic & 97.85 & 27 & 18 \\
\hline Netherlands & 97.15 & 28 & 4 \\
\hline Denmark & 96.41 & 29 & 8 \\
\hline Hungary & 95.82 & 30 & 29 \\
\hline Ireland & 95.84 & 31 & 13 \\
\hline Ukraine & 95.36 & 32 & 34 \\
\hline Finland & 94.31 & 33 & 2 \\
\hline Latvia & 94.10 & 34 & 20 \\
\hline Cyprus & 93.28 & 35 & 27 \\
\hline Spain & 92.69 & 36 & 16 \\
\hline Italy & 92.66 & 37 & 24 \\
\hline Portugal & 92.55 & 38 & 17 \\
\hline Slovenia & 90.51 & 39 & 32 \\
\hline Croatia & 87.96 & 40 & 35 \\
\hline Greece & 74.41 & 41 & 36 \\
\hline
\end{tabular}

Source: World Bank data site: http://data.worldbank.org/indicator/NY.GDP.MKTP.KD.ZG, date of access: April 22, 2015 
Marko Djogo, Nenad Stanisic •Is the Global Competitiveness Report the right measure...

Table A3: Ranking of European countries by criterion of investment/GDP ratio

\begin{tabular}{|c|c|c|c|}
\hline Country & $\begin{array}{c}\text { Investments } \\
(\% \text { of GDP in 2014.) }\end{array}$ & $\begin{array}{l}\text { Ranks by investments } \\
\text { (amid } 41 \text { countries) }\end{array}$ & GCR ranks \\
\hline Belarus & 37.744 & 1 & n.a. \\
\hline Estonia & 29.101 & 2 & 14 \\
\hline Norway & 26.830 & 3 & 7 \\
\hline Albania & 24.918 & 4 & 39 \\
\hline Bulgaria & 23.485 & 5 & 26 \\
\hline Moldavia & 22.687 & 6 & 37 \\
\hline Latvia & 22.528 & 7 & 20 \\
\hline Romania & 22.511 & 8 & 28 \\
\hline Czech Republic & 22.408 & 9 & 18 \\
\hline France & 22.108 & 10 & 12 \\
\hline Switzerland & 21.148 & 11 & 1 \\
\hline Austria & 20.924 & 12 & 11 \\
\hline Finland & 20.906 & 13 & 2 \\
\hline Serbia & 20.698 & 14 & 38 \\
\hline Poland & 20.619 & 15 & 21 \\
\hline Russia & 20.458 & 16 & 25 \\
\hline Belgium & 20.269 & 17 & 9 \\
\hline Slovenia & 20.09 & 18 & 32 \\
\hline Turkey & 19.869 & 19 & 22 \\
\hline $\mathrm{B} \& \mathrm{H}$ & 19.821 & 20 & n.a. \\
\hline Montenegro & 19.62 & 21 & 31 \\
\hline Lithuania & 19.602 & 22 & 19 \\
\hline Sweden & 19.194 & 23 & 6 \\
\hline Croatia & 19.124 & 24 & 35 \\
\hline Hungary & 18.824 & 25 & 29 \\
\hline Luxemburg & 18.753 & 26 & 10 \\
\hline Slovakia & 18.581 & 27 & 33 \\
\hline Netherlands & 18.116 & 28 & 4 \\
\hline Spain & 18.012 & 29 & 16 \\
\hline Germany & 17.701 & 30 & 3 \\
\hline Italy & 17.400 & 31 & 24 \\
\hline Denmark & 17.318 & 32 & 8 \\
\hline Malta & 16.895 & 33 & 23 \\
\hline Ireland & 16.433 & 34 & 13 \\
\hline Portugal & 15.703 & 35 & 17 \\
\hline Great Britain & 15.049 & 36 & 5 \\
\hline Iceland & 14.383 & 37 & 15 \\
\hline Greece & 13.798 & 38 & 36 \\
\hline Cyprus & 9.698 & 39 & 27 \\
\hline Ukraine & 8.161 & 40 & 34 \\
\hline
\end{tabular}

Source: Economy watch data site: http://www.economywatch.com/economic-statistics/economicindicators/Investment_Percentage_of_GDP/2014/ 